\title{
Total Synthesis of Dolabelide D
}

\author{
Peter K. Park, Steven J. O’Malley, Darby R. Schmidt, and James L. Leighton \\ Department of Chemistry, Columbia University, New York, New York 10027
}

In 1995 researchers reported the isolation and structural characterization of two new 22membered macrolides they termed dolabelides A and B from Japanese specimens of the sea hare Dolabella auricularia. ${ }^{1}$ These compounds exhibited cytotoxic activity against HeLa- $\mathrm{S}_{3}$ cells with $\mathrm{IC}_{50} \mathrm{~s}$ of 6.3 and $1.3 \mu \mathrm{g} / \mathrm{mL}$, respectively. Two years later, two new members of this class of natural products, dolabelides $\mathrm{C}$ and $\mathrm{D}$ were reported. ${ }^{2}$ These 24 -membered macrolides are also cytotoxic against $\mathrm{HeLa}-\mathrm{S}_{3}$ cells with $\mathrm{IC}_{50} \mathrm{~s}$ of 1.9 and $1.5 \mu \mathrm{g} / \mathrm{mL}$, respectively. This biological activity and the interesting stereostructure of these natural products have combined to elicit attention from synthetic chemists ${ }^{3}$ including our own group. ${ }^{4}$ Herein we describe our investigations that have led to the first total synthesis of dolabelide $\mathrm{D}$, by way of the synthesis and coupling of fragments $\mathbf{2}$ and $\mathbf{3}$ by esterification and ring-closing metathesis (Scheme 1).

The synthesis of fragment $2^{4}$ commenced with an application of our recently developed catalytic asymmetric silane alcoholysis ${ }^{5}$ with alcohol $\mathbf{4}$ and $t$-butyl-cis-crotylsilane to provide 5 as the major component of a 4:1 mixture of diastereomers in 95\% yield (Scheme 2). Rhodiumcatalyzed tandem silylformylation-crotylsilylation 6 proceeded stereospecifically to provide, after quenching with methyllithium, a 4:1 mixture of diastereomers favoring 1,5-syn-diol 6 in $56 \%$ yield. Selective protection of the less-hindered alcohol as its triethylsilyl (TES) ether led, after separation of the diastereomers, to the isolation of $\mathbf{7}$ in $74 \%$ yield. Treatment of alcohol 7 with $n$-BuLi and then $\mathrm{CuBr} \cdot \mathrm{SMe}_{2}$ and DMPU initiated a Brook-like 1,4 carbon $\left(\mathrm{sp}^{2}\right)$ to oxygen silane migration, ${ }^{7}$ and the resulting vinylcopper species was then alkylated with MeI to provide $\mathbf{8}$ in $92 \%$ yield. This sequence illustrates the power of the tandem silylformylation chemistry to provide access to different functionalities and substitution patterns in the 1,5-diol products. In addition, it is noteworthy that the $t$-butylsilane serves multiple purposes before being morphed into the desired $t$-butyldimethylsilyl (TBS) ether. A Wacker oxidation was optimized for concurrent removal of the TES ether, and the resulting alcohol 9 was acetylated to provide $\mathbf{1 0}$ in $78 \%$ overall yield ( 2 steps). Asymmetric aldol coupling 8 with 5 -hexenal then gave aldol 11 in 85\% yield and with >10:1 diastereoselectivity. Anti-diastereoselective (>10:1 dr) $\beta$-hydroxyketone reduction ${ }^{9}$ then gave $\mathbf{1 2}$ in $91 \%$ yield. Protection of the diol as a cyclopentylidene $\operatorname{ketal}^{10}$ gave $\mathbf{1 3}$ and TBS removal provided fragment $\mathbf{2}$ in 50\% yield (2 steps from 12). The synthesis of $\mathbf{2}$ was thus achieved in 10 steps and $11 \%$ overall yield from 4 .

Allylation of aldehyde $\mathbf{1 4}$ with our recently developed reagent $\mathbf{1 5}^{11}$ proceeded smoothly to provide 16 in $80 \%$ yield and $98 \%$ ee (Scheme 3). Protection of the alcohol as its $p$ methoxybenzyl (PMB) ether gave $\mathbf{1 7}$ in $95 \%$ yield, and was followed by a Wacker oxidation to give ketone 18 in $81 \%$ yield. Crotylation of methacrolein with crotylsilane ent-19 ${ }^{12}$, followed by protection of the resultant alcohol as its PMB ether produced $\mathbf{2 0}$ in $53 \%$ yield (based on ent-19, 2 steps) and 88\% ee. Hydroformylation in the presence of 2,2dimethoxypropane proceeded smoothly and selectively to give acetal $\mathbf{2 1}$ in $72 \%$ yield. StillBarrish hydroboration ${ }^{13}$ gave alcohol 22 with 13:1 $d r$. A 4 step oxidation-oxidationprotection-deprotection sequence then provided aldehyde $\mathbf{2 3}$ in $79 \%$ overall yield. 1,5-Anti selective aldol coupling ${ }^{14}$ of ketone $\mathbf{1 8}$ and aldehyde $\mathbf{2 3}$ proceeded smoothly to give aldol 
24 in 79\% yield as a 10:1 mixture of diastereomers. Protection of the alcohol as a triethylsilyl (TES) ether gave $\mathbf{2 5}$ in $94 \%$ yield and was followed by a diastereoselective $(\sim 5: 1)$ ketone reduction with L-Selectride to give 26. Following acetylation, the diastereomers were separated and $\mathbf{2 7}$ was isolated in $51 \%$ yield. Finally, deprotection of the allyl ester gave the target acid $\mathbf{2 8}$ in $92 \%$ yield. The synthesis of $\mathbf{2 8}$ was carried out with a longest linear sequence of 13 steps from methacrolein in $9 \%$ overall yield.

Esterification of alcohol $\mathbf{2}$ with acid $\mathbf{2 8}$ proceeded smoothly to give $\mathbf{2 9}$ in $\mathbf{7 4 \%}$ yield (Scheme 4). Methanolysis of the TES ether and cyclopentylidene ketal protecting groups was followed by oxidative cleavage of the PMB ether groups to provide pentaol $\mathbf{3 0}$ in $70 \%$ overall yield (2 steps). Initial attempts at macrocyclization by ring closing metathesis with the "secondgeneration" Grubbs catalyst 31 were plagued not only by (not unexpected) low stereoselectivity ( 1.3:1 E:Z), but also by significant amounts of byproducts presumably derived from olefin isomerization pathways. ${ }^{15}$ Despite these setbacks, dolabelide $\mathrm{D}$ could be isolated in $31 \%$ yield. Although a sample of the natural product was unavailable, comparison $\left({ }^{1} \mathrm{H}\right.$ and ${ }^{13} \mathrm{C}$ NMR, IR, HRMS, $\left.[\alpha]_{D}\right)$ to published data confirmed the identity of our synthetic material.

The first synthesis of dolabelide D (and of any of the dolabelides) has been achieved. Methodologically, the four step sequence that converts alcohol 4 into protected diol fragment $\mathbf{8}$ is especially noteworthy and serves as a demonstration of the power of the catalytic asymmetric silane alcoholysis and tandem silytformylation-crotylsilylation methods. That the pathway from alcohol 4 to dolabelide D comprises just 14 linear steps (the longest linear sequence is from methacrolein to dolabelide $\mathrm{D}$ in 17 steps) is testament to the efficiency of these methods.

\section{Supplementary Material}

Refer to Web version on PubMed Central for supplementary material.

\section{Acknowledgements}

The NIH (NIGMS GM58133) is acknowledged for their generous support of this work, and for a postdoctoral fellowship to D.R.S. P.K.P. is supported by the NIH Medical Scientist Training Program. We thank Bristol-Myers Squibb for a graduate fellowship to S.J.O.

\section{References}

1. Ojika M, Nagoya T, Yamada K. Tetrahedron Lett 1995;36:7491.

2. Suenaga K, Nagoya T, Shibata T, Kigoshi H, Yamada K. J Nat Prod 1997;60:155.

3. (a) Grimaud L, de Mesmay R, Prunet J. Org Lett 2002;4:419. [PubMed: 11820894] (b) Desroy N, Le Roux R, Phansavath P, Chiummiento L, Bonini C, Genêt JP. Tetrahedron Lett 2003;44:1763. (c) Le Roux R, Desroy N, Phansavath P, Genêt JP. Synlett 2005:429. (d) Keck GE, McLaws MD. Tetrahedron Lett 2005;46:4911. [PubMed: 16909163]

4. Schmidt DR, Park PK, Leighton JL. Org Lett 2003;5:3535. [PubMed: 12967318]

5. Schmidt DR, O’Malley SJ, Leighton JL. J Am Chem Soc 2003;125:1190. [PubMed: 12553820]

6. (a) Zacuto MJ, O’Malley SJ, Leighton JL. J Am Chem Soc 2002;124:7890. [PubMed: 12095319] (b) Zacuto MJ, O’Malley SJ, Leighton JL. Tetrahedron 2003;59:8889.

7. Taguchi H, Ghoroku K, Tadaki M, Tsubouchi A, Takeda T. Org Lett 2001;3:3811. [PubMed: 11700145]

8. (a) Paterson I, Goodman JM, Lister MA, Schumann RC, McClure CK, Norcross RD. Tetrahedron 1990;46:4663. (b) Paterson I, Florence GJ, Gerlach K, Scott JP, Sereinig N. J Am Chem Soc 2001;123:9535. [PubMed: 11572673]

9. Evans DA, Chapman KT, Carreira EM. J Am Chem Soc 1988;110:3560. 
10. For a discussion of the advantages of this diol protecting group, see: Evans DA, Connell BT. J Am Chem Soc 2003;125:10899. [PubMed: 12952470]

11. Kubota K, Leighton JL. Angew Chem Int Ed 2003;42:946.

12. Hackman BM, Lombardi PJ, Leighton JL. Org Lett 2004;6:4375. [PubMed: 15524487]

13. Still WC, Barrish JC. J Am Chem Soc 1983;105:2487.

14. (a) Paterson I, Gibson KR, Oballa RM. Tetrahedron Lett 1996;37:8585. (b) Evans DA, Coleman PJ, Côté B. J Org Chem 1997;62:788.

15 . The recently reported method to suppress such pathways did not provide significant improvement in this case. See: Hong SH, Sanders DP, Lee CW, Grubbs RH. J Am Chem Soc 2005;127:17160.

[PubMed: 16332044] 


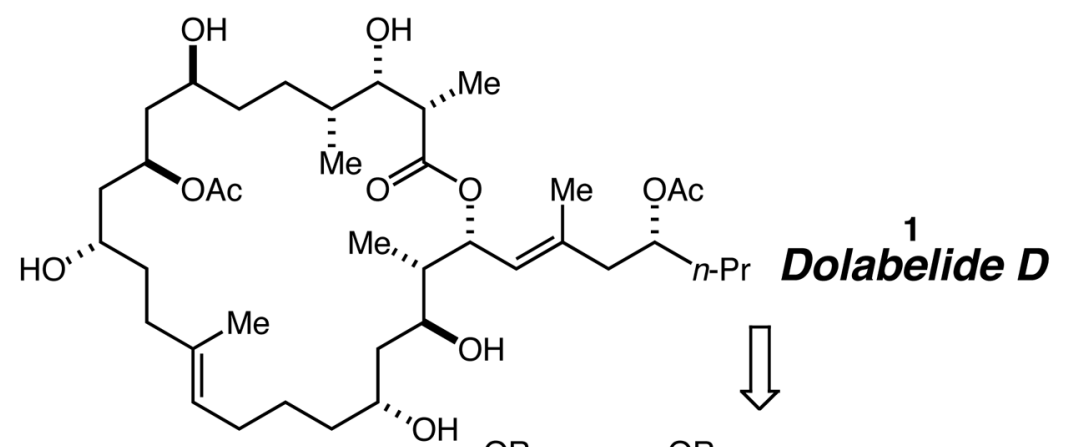

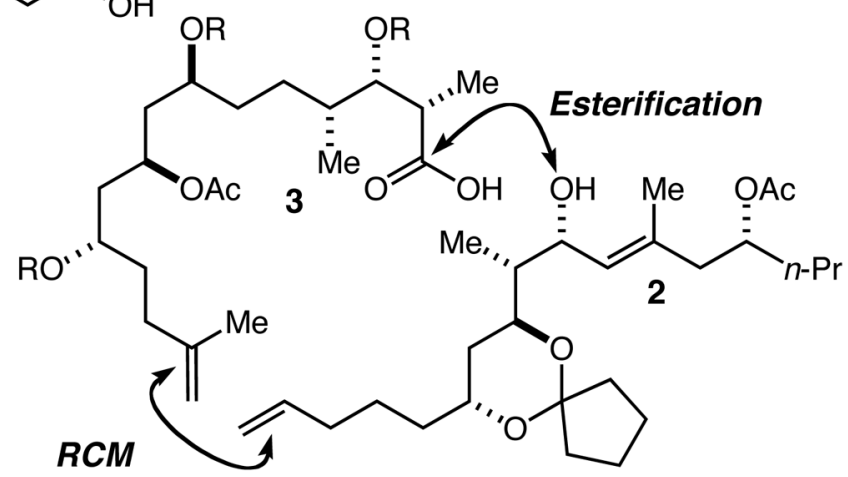

Scheme 1. 

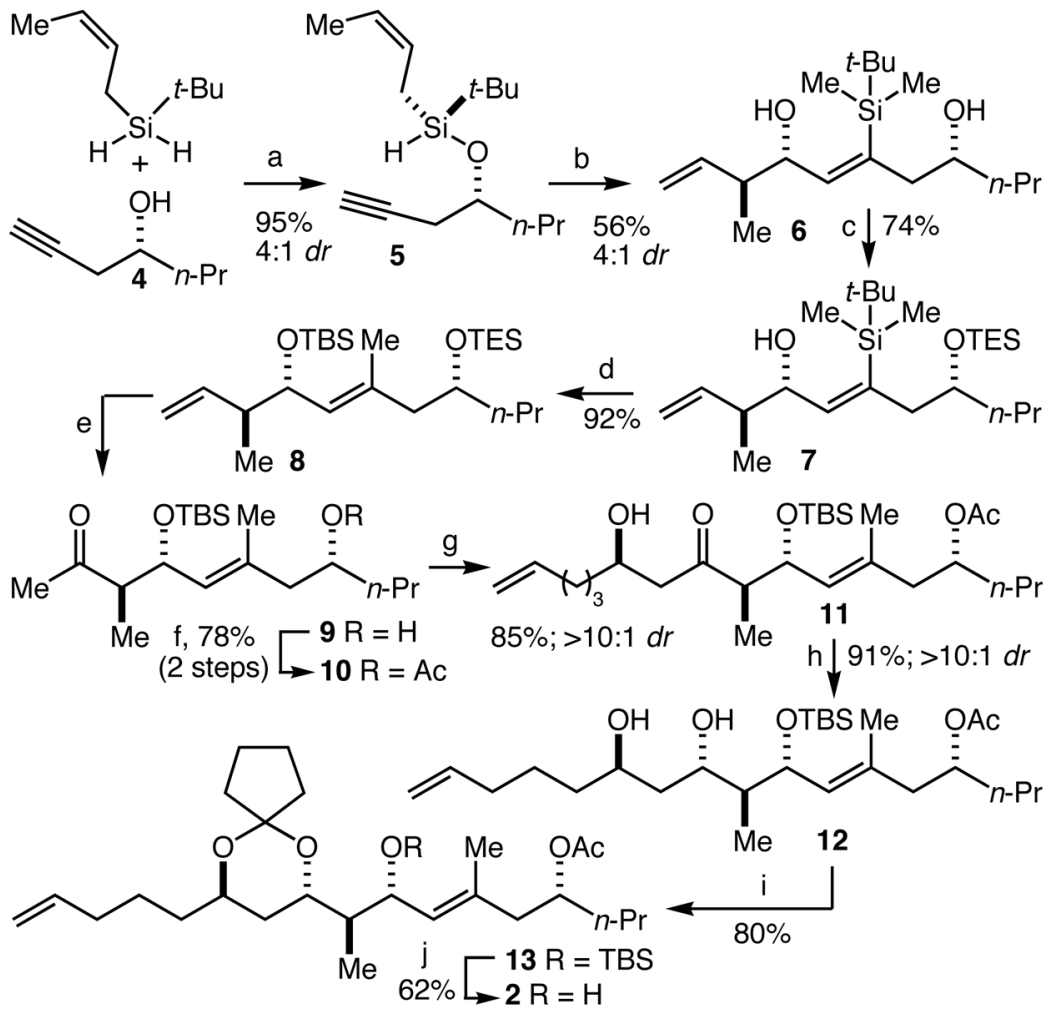

Scheme 2.

(a) $4 \mathrm{~mol} \% \mathrm{CuCl}, 4 \mathrm{~mol} \% \mathrm{NaO}-t$-Bu, 4 mol\% ( $R, R$ )-BDPP, PhH. (b) i. 2 mol\% [Rh (acetone $)_{2}-\left(\mathrm{P}(\mathrm{OPh})_{3}\right)_{2} \mathrm{BFF}_{4}, \mathrm{CO}, \mathrm{PhH}, 60{ }^{\circ} \mathrm{C}$; ii. $\mathrm{MeLi}, \mathrm{Et}_{2} \mathrm{O}-78$ to $23{ }^{\circ} \mathrm{C}$. (c) $\mathrm{TESCl}, \mathrm{Et}_{3} \mathrm{~N}$, $\mathrm{CH}_{2} \mathrm{Cl}_{2},-20{ }^{\circ} \mathrm{C}$. (d) $n$-BuLi, THF, $-78{ }^{\circ} \mathrm{C}$; $\mathrm{CuBr} \bullet \mathrm{Me}_{2} \mathrm{~S}$, DMPU, $23{ }^{\circ} \mathrm{C}$; MeI, -78 to $23{ }^{\circ} \mathrm{C}$. (e) $25 \mathrm{~mol} \% \mathrm{PdCl}_{2}, \mathrm{CuCl}, \mathrm{DMF}, \mathrm{THF}, \mathrm{H}_{2} \mathrm{O}, \mathrm{O}_{2}$. (f) $\mathrm{Ac}_{2} \mathrm{O}$, pyridine, DMAP, $\mathrm{CH}_{2} \mathrm{Cl}_{2}$. (g) (+)(ipc) ${ }_{2} \mathrm{BCl}, \mathrm{Et}_{3} \mathrm{~N}, 5$-hexenal, $\mathrm{Et}_{2} \mathrm{O}-78$ to $23{ }^{\circ} \mathrm{C}$. (h) $\mathrm{Me}_{4} \mathrm{NBH}(\mathrm{OAc})_{3}, \mathrm{AcOH}, \mathrm{CH}_{3} \mathrm{CN}, \mathrm{THF}$, -40 to $-20{ }^{\circ} \mathrm{C}$. (i) 1,1-dimethoxycyclopentane, PPTS, $\mathrm{CH}_{2} \mathrm{Cl}_{2}$. (j) $n$ - $\mathrm{Bu}_{4} \mathrm{NF}$, THF. 


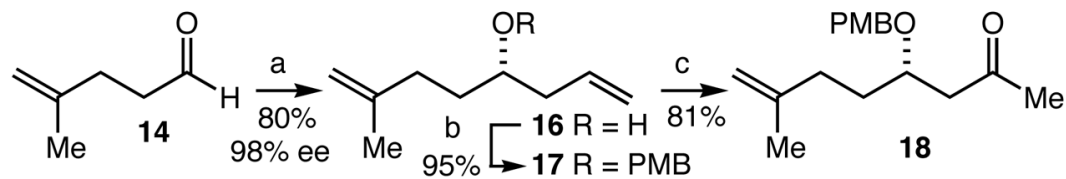

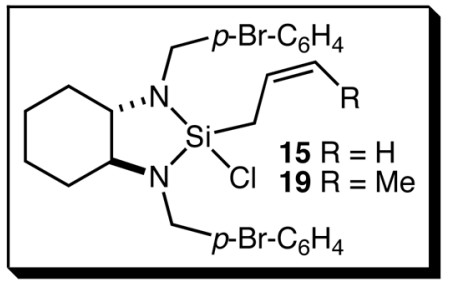<smiles>CC(C=O)=CC=[18O]</smiles><smiles>C=CC(=C)[C@@H](O[R16](=O)OC)C(C)C</smiles>

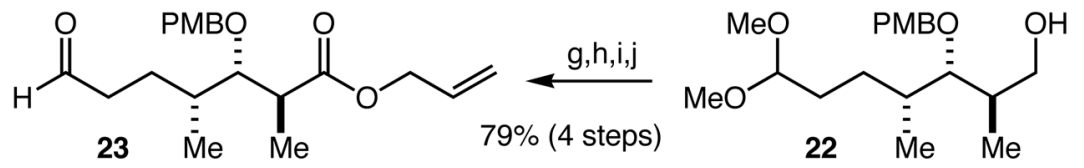

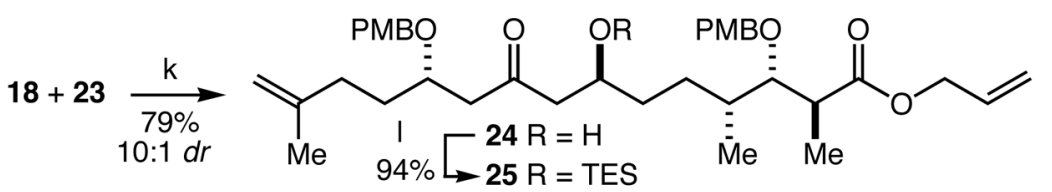

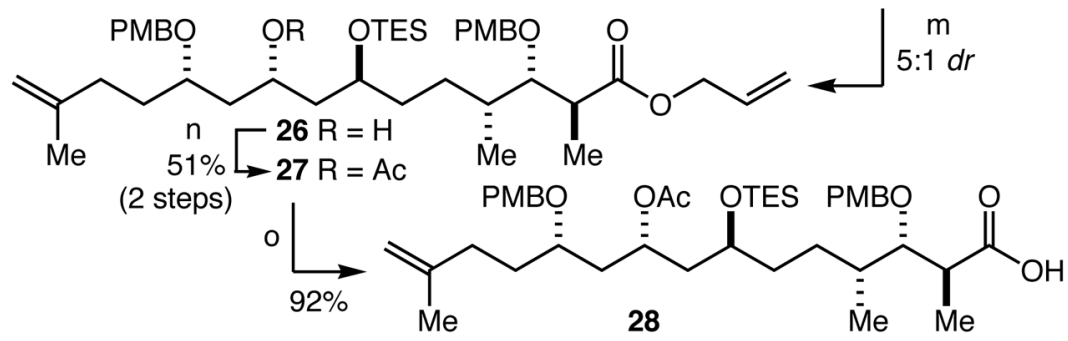

Scheme 3.

(a) 15, $\mathrm{CH}_{2} \mathrm{Cl}_{2},-20{ }^{\circ} \mathrm{C}$. (b) $\mathrm{NaH}, \mathrm{PMBBr}$, THF, reflux, (c) $25 \mathrm{~mol} \% \mathrm{PdCl}_{2}, \mathrm{CuCl}, \mathrm{DMF}$, $\mathrm{H}_{2} \mathrm{O}, \mathrm{O}_{2}$. (d) ent-19, $\mathrm{CH}_{2} \mathrm{Cl}_{2}$. (e) $2 \mathrm{~mol} \% \mathrm{Rh}(\mathrm{acac})(\mathrm{CO})_{2}, 10 \mathrm{~mol} \% \mathrm{PPh}_{3}, \mathrm{H}_{2} / \mathrm{CO}, 2,2-$ dimethoxypropane, PPTS, $60{ }^{\circ} \mathrm{C}$. (f) 9-BBN, THF, -78 to $23{ }^{\circ} \mathrm{C} ; \mathrm{H}_{2} \mathrm{O}_{2}, \mathrm{NaOH}$. (g) $(\mathrm{COCl})_{2}$, DMSO, Et ${ }_{3} \mathrm{~N}, \mathrm{CH}_{2} \mathrm{Cl}_{2},-78{ }^{\circ} \mathrm{C}$. (h) $\mathrm{NaClO}_{2}, \mathrm{NaH}_{2} \mathrm{PO}_{4}, 2$-methyl-2-butene, $t$-BuOH, $\mathrm{H}_{2} \mathrm{O}$. (i) $\mathrm{K}_{2} \mathrm{CO}_{3}, \mathrm{CH}_{2}=\mathrm{CHCH}_{2} \mathrm{Br}$, acetone, reflux, (j) PPTS, acetone, $\mathrm{H}_{2} \mathrm{O}$, reflux, (k) n-Bu $2 \mathrm{BOTf}$, $i$ $\mathrm{Pr}_{2} \mathrm{NEt}, \mathrm{Et}_{2} \mathrm{O},-110^{\circ} \mathrm{C}$. (1) TESCl, imidazole, $\mathrm{CH}_{2} \mathrm{Cl}_{2}$. (m) L-Selectride, $\mathrm{CH}_{2} \mathrm{Cl}_{2},-78^{\circ} \mathrm{C}$. (n) $\mathrm{Ac}_{2} \mathrm{O}$, pyridine, DMAP, $\mathrm{CH}_{2} \mathrm{Cl}_{2}$. (o) $10 \mathrm{~mol} \% \mathrm{Pd}\left(\mathrm{PPh}_{3}\right)_{4}$, morpholine, THF. 


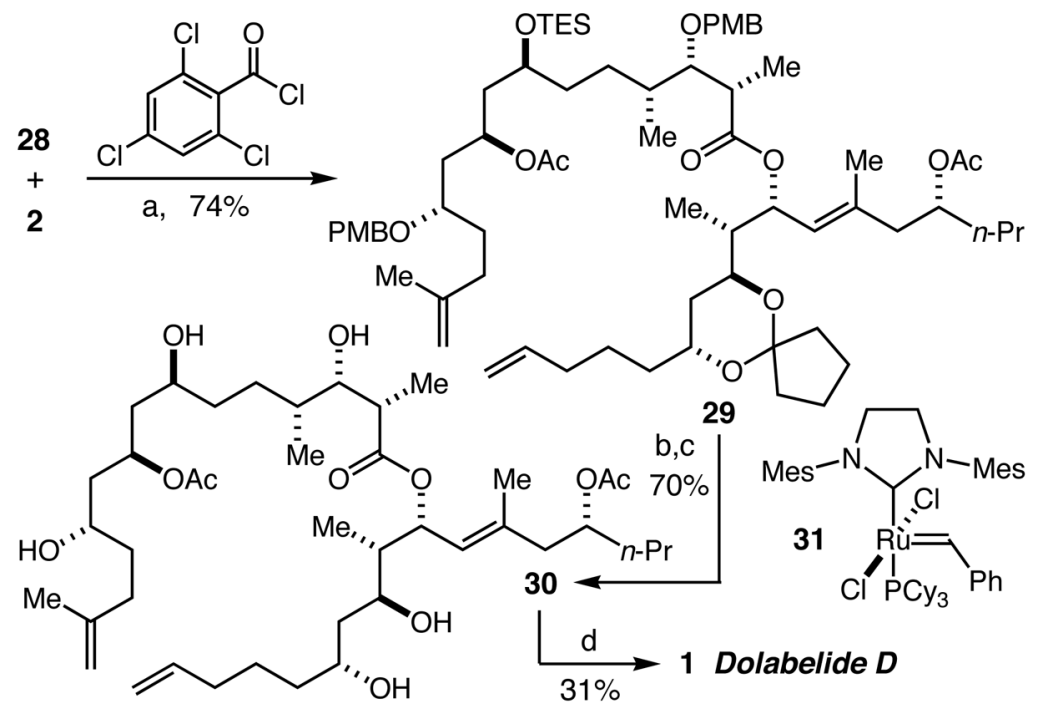

Scheme 4.

(a) $\mathrm{Et}_{3} \mathrm{~N}$, DMAP, toluene, -78 to $0{ }^{\circ} \mathrm{C}$. (b) PPTS, MeOH. (c) DDQ, $\mathrm{CH}_{2} \mathrm{Cl}_{2}, \mathrm{pH} 7$ buffer, (d) $25 \mathrm{~mol} \% 31, \mathrm{CH}_{2} \mathrm{Cl}_{2}$, reflux. 